\title{
A Framework for Accreditation of \\ International Baccalaureate School
}

\section{Libraries}

\author{
Peter Warning \\ Lecturer \\ University of Hong Kong \\ Hong Kong \\ pwarning@hkucc.hku.hk \\ James Henri \\ President \\ International Association of School Librarianship \\ Hobart \\ Carolyn Sinclair \\ Rosebank College Sydney \\ Chan Ching Yee Candy \\ University of Hong Kong \\ Hong Kong \\ Beckie CHU \\ University of Hong Kong \\ Hong Kong
}

This study proposes a framework for an accreditation process for International Baccalaureate (IB) school libraries. It investigates a range of existing library benchmarks from developed countries as well as criteria for school library evaluation. A partner for this study is the International Association for School Librarianship (IASL). IASL will include the results of this study as it considers its role as an accrediting body for IBO school libraries. The areas for evaluation, and resulting accreditation, include: staffing, collections, services, facilities and equipment, and collaboration and networking.

School library benchmarks; international school libraries; library accreditation 


\section{Introduction}

This study proposes an accreditation process for IB school libraries. It investigates a range of existing library benchmarks from developed countries that can act as guides. The International Association for School Librarianship (IASL) is a partner in this study. They may repackage the results of this study and offer to act as an accrediting body for IBO and other international secondary school libraries. The accreditation project was originally conceived in 2007. Subsequently, IASL established a task force in 2008 to develop the standards. The present study was started independently of the task force. It is expected that the task force will consider incorporation of the results of this study into its final recommendations. Essentially, this study takes on the status of an issues document.

Performance standards and benchmarks have been introduced and maintained over a long period of time to measure performance in an almost infinite number of activities and products. Standards may be implemented by international, national and local organizations, as well as governments. The International Standards Office (ISO) is the example par excellence of a standards creating body. It was established in 1947 with the stated purpose "to facilitate the international coordination and unification of industrial standards" (ISO, 2008). Operating as a network of national standards institutes of 157 countries, it has created or applied standards to over 16,500 activities and products. More recently within the library world, a range of standards have been established. The most obvious relate to collections. So, for example, Conspectus was established in the early nineteen-eighties by the Research Libraries Group (RLG). It applies quantitative and qualitative measures to library collections and has a rating system for library collections and parts of library collections. One of the original intentions of Conspectus was to enable researchers to identify collections rich in the subject areas in which they are researching. An implication of this is that they could choose to use these collections to progress their research. The writers see a parallel between this element of Conspectus and the role of accreditation for school libraries. There is a tradition of research that demonstrates correlations between the standard of a school library and the academic performance of its students. An extension of this is that the accreditation of a school library by a reliable accrediting body gives some assurances to parents that the school is more likely to achieve their desired academic outcomes. That is, it can help to inform their decisions relating to their children's education.

There are other obvious advantages of accreditation based on performance standards relating to the improved performance of school libraries. As noted by CILIP, a series of guidelines or standards can act "as practical guidance and material for advocacy" (CILIP, 2004, p. XIII) for those who manage school libraries. This is echoed in the IFLA guidelines for school libraries, which were "produced to inform decision makers at national and local 
levels around the world, and to give support and guidance to the library community" (Saetre, 2002 , p. 2). Well constructed standards can point to areas that need improvement. This point is also noted by the IBO, whose library standards were established "to encourage the development of the library as a learning resources centre in schools following the International baccalaureate programmes. (Committee for IB Librarians in Africa/Europe/Middle East, 1999, p. 1)"

The focus of this study is IB school libraries, but the expectation is that it can be extended to international schools in general. The researchers argue that standards are more effective as they become more specific. As noted by the IBO, the IB programme has specific demands that may require customisation of standards. (Committee for IB Librarians in Africa/Europe/Middle East, 1999) As most IB schools are international and non-government schools, the extension of the standards to non-IB schools is logical. Of course this would involve the solicitation of accreditation by the schools and their participation in the accreditation process.

The International Baccalaureate is an educational programme for elementary, middle, and high schools designed to provide the schools with an international curriculum intended to be acceptable for university entrance globally (Wikepedia, 2007). It is administered by the International Baccalaureate Organization (IBO), an international non-profit educational foundation, founded in 1968. Currently there are more than 582,000 IB students at 2,167 schools in 125 countries, including 19 schools in Hong Kong (International Baccalaureate Organization, 2007). The IB is becoming more influential as more schools adopt its syllabus. Resource based learning is an important element of the IB, intensifying the importance of the library. The IBO has a dedicated librarians' page which includes links to resource based learning materials.

\section{Methodology}

The methodology was informed by a review of the literature on school library evaluation and benchmarking. The rationale for investigating evaluation techniques is that it is only worth evaluating things that matter, whether they be physical things (e.g. collections) or activities (e.g. information literacy programmes). Evaluation becomes meaningful when it involves realistic performance indicators.

Existing school library benchmarks from a range of school systems have been analysed. These benchmarks, taken as a corpus, provide a huge range of potential library areas to be included in the standards. They also display significant similarities as well as differences in the metrics attached to many of the performance indicators. Some use raw 
numbers, others percentages or per capita ratios. As noted in the IFLA Guidelines, "guidelines will need to be read and used within a local context" (Saetre, 2002, p. 2). A simple example is space. In a space rich country like Australia, the standards for seating within the library are more liberal (i.e. the ASLA/ALIA standards recommend seating for 12 percent of the student population) than in other areas, such as the United Kingdom (CILIP standards recommend seating for 10 percent of the student population) where population densities are higher.

In order not to operate in a vacuum, visits to IB school libraries and interviews with teacher librarians, teachers and principals at IB schools in HK are planned. These will determine that the standards describe realistic levels of performance. Returning to the seating issue, 10 percent of students having access to seating in the library at any time would be unrealistic, due to the general limitations of space in Hong Kong. The deleterious effects of lack of seating can be mitigated by increased remote access.

\section{Literature review}

As indicated above, accreditation needs to be based on observable and measurable features that contribute to school library performance. A review of the literature indicates that these issues frequently surface in benchmarking and evaluation of library services and collections etc. This summary literature review is drawn from education and library databases like ERIC and LISA, as well as books, websites of government agencies and professional bodies like Missouri Department of Elementary and Secondary Education, American Library Association (ALA), California School Library Association (CSLA), International Federation of Library Associations and Institutions (IFLA) and School Library Association (SLA). Throughout this paper, the terms, school librarian and teacher librarian will be used synonymously.

\section{School library evaluation and benchmarking}

Introduction. An expanding body of research indicates that the performance of the school library is closely linked to the academic achievement of its students. Lance \& Loertscher (2002) state clearly that strong school library media programs make a difference in academic achievement based on findings from numerous research studies across American states such as: Alaska, Colorado, Pennsylvania, Massachusetts, Texas and New Mexico involving over 3,300 schools. School libraries with bigger budgets, bigger collections and higher levels of librarian staffing have higher reading scores (Lance \& Loertscher, 2002). Well equipped quality school library media centers contribute to the academic success of their students. The issue is: what comprises a well equipped quality school library media center? 
Evaluation and Benchmarking. To justify a claim of being an exemplary school library or have high quality library media programmes, a library needs to comply with accepted professional standards established by authoritative organizations or related government departments. To achieve this goal, regular and robust evaluation of the library is essential. Through evaluation and comparison benchmarks, school libraries can identify their level of quality relative to other similar libraries within broad bands. Where deficiencies are identified, improvements can be undertaken. This continuous improvement is a crucial procedure for school library accreditation processes. Evaluation of the school library has multiple facets. The physical environment should support its role as a whole-school learning resource at the heart of the school community (CILIP, 2004). In an era of unparalleled information growth, being information literate is essential, "learning how to learn has become as important as the learning of the disciplines themselves" (Committee for IB Librarians in Africa/Europe/Middle East, 1999). Dzikowski (2003) found that students in schools with professional library media specialists perform better on achievement tests for reading comprehension and basic research skills confirming that professional library media specialists pay an important role in the library. In Standards and Guidelines for Strong School Libraries (Abilock, 2004), standards for different levels of library staff, library media teachers, library media supervisors and paraprofessionals, are described in detail. Though international standards are usually good guidelines, librarians should not neglect the individual characteristics of local users. Adjustment should be made to fit the needs.

The accreditation process mainly performs two primary functions: quality assurance and institutional improvement. Quality assurance acts as a tool to help organizations meet standards relating to the specific services provided. The other function is institutional improvement, where accreditation provides a review of different components of institutions, which assist and stimulate improvement to work towards the goals (Dalrymple, 2001).

The elements of a school library accreditation process should include the following:

Staffing. Staffing is an essential resource to operate an effective school (School Library Association, 1989). The number of staff required for a school library will depend on type, size and demands of the school. The SLA recommends that each school should have a teaching staff with responsibility for the development of library resources. The library should be staffed throughout the school day to help library users and to keep the library open. The person in charge of the library (a) chartered librarian and (b) teacher librarian to manage the library. Other levels of staff may be assigned to the operation of the school library, e.g. clerical assistants to assist in circulation process and non professional tasks; technical assistants to solve IT issues; parent and pupil volunteers trained by the librarian to assist 
library in different functions. Similarly, the South Dakota Library Association (2005) recommends that the school should have at least full-time certified librarian and clerical staff.

Ideally the teacher librarian should have qualifications in both information management and education (ie. librarianship and teaching qualification). He or she should have knowledge about curriculum development, resource management and information technology systems (Australian Association of School Librarians \& Australian Library \& Information Association, 2007). IFLA (Saetre, 2002) found that a quality school library consists of both full time and part time library staff, and also volunteers (e.g. student helpers and parent volunteers) to support some daily operations.

Collection. The school library must have resources appropriate to meet the curriculum needs in quantity and quality (Massachusetts School Library Media Association, 1997). The collection should be: accessible to all users; curriculum relevant; be up to date; and user appropriate. A later study (Australian Association of School Librarians \& Australian Library \& Information Association, 2007) provides guidelines for selection of library resources. Library resources should be "selected by professional staff with knowledge of curriculum, learning styles, collection development, ICT and resource-selection tools (e.g. book reviews)". Other issues such as censorship and intellectual freedom in the selection process should be considered. The resources should encompass a variety of formats include print and non print items, which match the needs of student learning, so the ratio of print and non print items should have a balance between different needs. Also the currency of the collection, represented best by median age should be monitored regularly to keep it at less than ten years depending on the nature of the resources.

\section{Frameworks used}

A range of documents dealing with school library benchmarks were derived from North America, Australasia and Europe. They include standards from international, national and provincial school and library associations. Although there are other potential sources that have similar content, the researchers believe that saturation was achieved using the sources below. The following documents were analysed to contribute to the recommended framework: Massachusetts School Library Media Association, Standards for School Library Media Centers in the Commonwealth of Massachusetts (1997); National Library of New Zealand, School Libraries in New Zealand (Slyfield, 2001); Australian School Library Association \& ALIA, Learning for the Future. $2^{\text {nd }}$ ed (2001); IFLA/UNESCO, School Library Guidelines (Saetre, 2002). Minnesota School Library Media Association, The results of the school library media program census (U.S. Department of Education, 2006); South Dakota Library Association \& School Library Standards Committee, South Dakota School 
Library Standards (2005); California School Library Association, Standards and Guidelines for strong school libraries (Abilock, 2004); Missouri Department of Elementary \& Secondary Education, Standards for Missouri School Library Media Centers (2005); Booktrust School Libraries Research, Booktrust School Libraries Research (2007); CILIP, CILIP guidelines for secondary school libraries, $2^{\text {nd }}$ ed (2004); National Library of Canada, Elementary and Secondary Schools: The Role, Challenges and Financial Conditions of School and School Library Resources in Canada (2001); Committee for IB Librarians in Africa/Europe/Middle East, Guidelines for School Libraries (1999).

Of the published resources, the researchers consider that the CILIP, IFLA/UNESCO, ASLA/ALIA and California School Library Association (CSLA) reports provide comprehensive, holistic, and detailed indicators that are appropriate for international secondary school libraries. The IB Guidelines, customized to the IB situation are also apposite. These provide the basis for the bulk of the recommended accreditation standards, supplemented by the other sources where appropriate. Interviews with experts in the field were also conducted to surface other factors that teacher Librarians considered important for providing high-level library services. Categories representing the range of school library activities were extracted from these documents and interviews and where suitable, numeric indicators were applied to them in order to identify the level of school library performance. A survey is planned for a sample of IB school libraries in Hong Kong to gauge realistic levels of performance. At the time of writing, the data had not been analysed.

\section{Accreditation levels}

A number of frameworks have a multi-level rating scheme with 3 levels, for example:

\begin{tabular}{cccc} 
Framework & Lowest level & Middle level & Highest level \\
\hline $\begin{array}{c}\text { South Dakota School } \\
\text { Library Standards }\end{array}$ & At risk & Basic & Exemplary \\
$\begin{array}{c}\text { California School } \\
\text { Library Association }\end{array}$ & At risk & Making progress & Exemplary \\
$\begin{array}{c}\text { National Library of New } \\
\text { Zealand }\end{array}$ & Needs developing & Developing & $\begin{array}{c}\text { Good/standard/ } \\
\text { satisfactory }\end{array}$ \\
$\begin{array}{c}\text { Minnesota Educational } \\
\text { Media Organization }\end{array}$ & Minimum & Standard & Exemplary \\
\hline
\end{tabular}

Table 1: Three-tiered accreditation schemas

Not all systems use a three-level scheme. For example, Massachusetts School Library Media Association and Texas School Libraries (Ester \& EGS Research \& Consulting, 2001) both adopt a four-level schema. 


\begin{tabular}{ccccc} 
Framework & $\begin{array}{c}\text { Lowest } \\
\text { level }\end{array}$ & Middle levels & $\begin{array}{c}\text { Highest } \\
\text { level }\end{array}$ \\
\hline $\begin{array}{c}\text { Massachusetts School } \\
\text { Library Media } \\
\begin{array}{c}\text { Association } \\
\text { Texas School Libraries }\end{array}\end{array}$ & Deficient & Basic & Proficient & Exemplary \\
& $\begin{array}{c}\text { Below } \\
\text { standard }\end{array}$ & Acceptable & Recognized & Exemplary \\
\hline
\end{tabular}

Table 2: Four-tiered accreditation schemas

The researchers have adopted the three tier structure and used the following terminology:

\begin{tabular}{|c|c|c|}
\hline Level & Label & Description \\
\hline Lowest & Conditional & Accreditation based on improvements to..... \\
\hline Middle & Satisfactory & $\begin{array}{l}\text { Library supports and sustains critical teaching and learning } \\
\text { activities within the school }\end{array}$ \\
\hline Highest & Exemplary & $\begin{array}{l}\text { To be used as a model/exemplar for other libraries to emulate. } \\
\text { Library exceeds satisfactory levels of support for critical teaching } \\
\text { and learning activities within the school in a number of areas }\end{array}$ \\
\hline
\end{tabular}

Table 3: Recommended three-tiered accreditation schemas

The researchers consider that it is not appropriate to completely withhold accreditation from a school library that does not reach the minimum required standards. Rather, it is more desirable to make recommendations for improvement that, if achieved, will lead to accreditation for underperforming school libraries. A potential risk of establishing such standards is that they may become defacto minimum standards. This is undesirable as it may retard the progression towards excellence. So the third category is that of exemplary, which matches a number of school library standards. The identification of exemplars can provide a model for other schools to learn from and apply, where appropriate, to their local conditions.

\section{Categories for evaluation}

The following entries include samples from the benchmarks, surveys and other relevant documents plus recommended levels.

\section{Collections}

Size: 8 books per pupil (Booktrust); 10 books per student (IFLA); 12 items per student (New Zealand); 17 items per student (CILIP, ASLA/ALIA); 20-25 items per user, including access to outside collections (IBO); 22 items per student (Massachusetts). Recommended: Satisfactory - 15-25 items per student; Exemplary - more than 25 items per 
student.

Collection currency - i.e. publication date of collection. $70 \%$ of entire collection will have a copyright date no later than 10 years (Massachusetts). Average copyright year 10 years before current date (Minnesota); average age of less than 10 years (ASLA/ALIA). 10\% of library stock to be replaced annually (CILIP). Recommended: Satisfactory - median age of 10 years or less; Exemplary - median age of collection less than 7 years.

Popularity - based on circulation statistics and in-house usage statistics. Recommended: Satisfactory - recording and analysis of circulation statistics to identify overand under-used parts of the collection; Exemplary - recording and analysis of circulation and in-house usage statistics to identify over- and under-used parts of the collection.

Fiction: non-fiction ratio. 1:4-1:5 (CILIP); At least 60\% of stock should consist of curriculum related non-fiction resources (IFLA). Recommended: Satisfactory - fiction: nonfiction -1:4-1:5; no Exemplary recommendation.

Serials, newspapers etc. Median access to 20 full-text titles (New Zealand); access to 40-100 full text titles include print and electronic depending on school size (Massachusetts); 0-23, at risk, 24-49, making progress, 50+ exemplary (California). Recommended: Satisfactory - provide access to at least 20 print and online periodical databases; Exemplary - provide access to at least 50 print online periodical databases and print periodicals.

Different media, e-resources, audio visual, links to free internet resources etc. Titles should equal $1 \%$ of total print collection (Massachusetts); $30 \%$ of the collection budget allocated to non-print materials; audio visual materials at least $33 \%$ of print materials budget (South Dakota). Recommended: Satisfactory - non-print materials should total at least 1\% of total print titles; Exemplary - non-print materials should total at least 2\% of total print titles based upon collection development policy.

Collection focused on curriculum. Resource Based Learning etc: at least $60 \%$ of collection consists of curriculum-related resources (IFLA); be curriculum relevant and be user appropriate (Massachusetts); meet curriculum needs and student interests (South Dakota); appropriate levels for all resource-based units and meet personal and recreational needs (ASLA/ALIA). Recommended: Satisfactory - at least $60 \%$ of collection consists of curriculum-related resources; no Exemplary recommendation. 
Online databases. Electronic subscription services total at least 3\% of total collection (ASLA/ALIA); Audio visual materials at least 33\% of print materials budget, computer software/online resources at least $40 \%$ of print materials budget (South Dakota). ; no Recommendation: Satisfactory - electronic subscription services total at least 3\% of total collection; Exemplary - electronic subscription services total at least $10 \%$ of total collection with multiple simultaneous usage to online database.

Professional collection for Teacher Librarian. Basic- less than US\$100 per annum spent on professional library resources, exemplary- more than US\$100 per annum spent on professional library resources (South Dakota). Recommended: Satisfactory - at least US\$110 per annum spent on professional library resources; Exemplary - more than US\$110 per annum spent on professional library resources.

Collection development policy. Elements should include: statements of intellectual freedom, freedom of information, purpose of the collection management policy, long and short term objectives (IFLA). Recommended: Satisfactory - policy should describe: process of analysis, selection and evaluation, followed by the collection development policy. It should also include Challenged titles policy and Weeding/deselection policy (see below). Policy should be ratified by the school board (or equivalent body) and be updated every three years; Exemplary - as above and policy should be updated annually.

Weeding/deselection policy, including numeric guidelines for weeding/ deselection. Worn and inappropriate material is discarded, with at least $10 \%$ items replaced annually (ASLA/ALIA, SLA, IBO). Recommended (1): Satisfactory - weeding is performed on a regular basis; Exemplary - weeding is performed applying the collection development plan which defines deselection criteria according to written standards, e.g. age of materials, non-usage of materials etc. Recommended (2); Satisfactory at least 10\% items replaced annually; Exemplary - at least 10\% items replaced annually, with particular attention to tine sensitive materials e.g. IT materials, which should generally be replaced/discarded every 2-3 years.

Annual acquisitions budget. \$3-\$15 per student for books (Association of Canadian Publishers); $£ 4.28$ per head (survey) $£ 14$ (recommended) (Booktrust); median per student budget for library resources of $\$ 14$ (New Zealand); satisfactory, at least US \$16 per student; exemplary US\$30 per student (South Dakota). Recommended: Satisfactory -US\$33 per student; Exemplary - US\$40 per student.

Regular evaluation of collection using collection mapping or similar framework. 
Schools should apply existing guidelines for stocking and maintaining school libraries (Booktrust); performance statistics to determine which sections of stock need investment (IBO); involve students and staff by encouraging them to identify stock gaps and recommend purchases, carry out annual stock checks and regular reviews and evaluation of stock, to measure relevance to existing demands and plan for future development (CILIP). Recommended: Satisfactory - regular evaluation of the quality and quantity of the collection, using established methodologies such as collection mapping and $\mathrm{RBH}$.

\section{Facilities}

Function and use. Custom built library, dedicated to library use, reading areas, ICT areas, group study areas (SLA); exclusively for activities related to reading and learning (Booktrust). Recommended: Satisfactory - dedicated and permanent space for quiet reading, use of IT, group study, multimedia; Exemplary - as above with custom built and exclusive use for library that allows for expansion and remodeling.

Location. On one floor only, preferably the ground floor (CILIP); central location, on the ground floor (IFLA); ground floor with vehicular access (SLA). Recommended: Satisfactory - not centrally located but easy to access; matching local building requirements such as: fire safety, disabled access, etc; Exemplary - one floor, centrally sited, easy access and with vehicular access.

Space. Seating for 10 percent of school's students (CILIP/SLA); 12 percent (ASLA/ALIA); 5-10 percent (IBO). Recommended: Satisfactory - seating for $5-10 \%$ of students; Exemplary - seating for more than $10 \%$ of students. Gross space $0.413-0.463$ $\mathrm{m} 2 / \mathrm{student}$ (CILIP); $0.57 \mathrm{~m} 2 / \mathrm{student}$ (ASLA/ALIA). Recommended: Satisfactory - 0.38$0.463 \mathrm{~m} 2 /$ student; Exemplary - greater than $0.463 \mathrm{~m} 2 /$ student

Environment: Temperature, lighting, colour scheme, music, ventilation, signage all need to be taken into account for different types of users (CILIP); safety, good lighting, functional and aesthetic appearance (IFLA); ergonomically appropriate furnishings, good lighting and sound control, attractive colors and textures (Massachusetts). Recommended: Satisfactory - the environment meets with basic standards, e.g. inappropriate colour schemes (e.g. red and hot orange) are not chosen; proper lighting, sound control (no sound); Exemplary - all factors considered at design stage and librarians work closely with architects and designers, refer to library standards, e.g. temperature $<70 \mathrm{~F}, 50$ percent relative humidity for general library, demonstrate flexibility to suit different learning styles, e.g. co-existence of sound control zones, with soft music area and silent areas. 
Library budget. Specific library budget (i.e. not incorporated into other department budgets) and mandated percentage of school budget: at least 5 percent of per student expenditure (IFLA); 10 percent annual replacement +5 percent growth (IBO); 1-3 percent of school's instructional budget (Texas). Recommended: Satisfactory - 5 percent student expenditure; Exemplary - over 5 percent student expenditure.

\section{Equipment}

Photocopier, colour photocopier. A photocopier is useful to have in a library (IB). Recommended: Satisfactory - black \& white photocopier; Exemplary - colour photocopier.

Fax machine. Spare phone lines for fax (ASLA/ALIA). Recommended: Satisfactory - access to school fax machine; Exemplary - fax machines within the library.

Printer. At least one laser and inkjet printer (Minnesota). Recommended: Satisfactory - one laser printer; Exemplary - more than one colour laser and inkjet printer.

Scanner: Provide access to scanning equipment (IFLA). Recommended: Satisfactory - access to scanning equipment only; Exemplary - scanning equipment available within the library.

Computer. 1 workstation for each library staff (ASLA/ALIA); including electronic catalog, circulation system, connect to LANs and WANs (Missouri). Recommended: Satisfactory - staff and students have individual access to computers; Exemplary - for students and teachers to access the information resources provided through the library, access to adequate terminals throughout user areas.

Standalone workstation - eg with internet access, with workstation and internet access, with wireless network. 401-800 students at least 16 workstations (Massachusetts); no. of workstations equal to or greater than $1 / 3$ of class size (Missouri). Recommended: Satisfactory - computers for $1 / 3$ of average class size; Exemplary computers for more than $1 / 3$ of average class size.

Laptop - internal use, external use. At least one portable computer (Minnesota). Recommended: Satisfactory - laptop only for internal use; Exemplary - laptops can be lent for external use (both students and teachers).

Computer software (e.g. MS Office). Be accessible to all users, curriculum relevant, up to date, user appropriate (Massachusetts). Recommended: Satisfactory - provide 
training for library staff and provide up-to-date software. Exemplary - as above plus sufficient time to evaluate software and applicability to the school curriculum.

Multimedia equipment, eg camera, video camera, Digital Video Disc (DVD), Player Compact Disc (CD) Player. Provide access to audiovisual equipment (IFLA); enable students and faculty using a variety of equipment to creatively design, produce and make presentations (Missouri). Recommended: Satisfactory - provide access for in house use only, Exemplary - have range of multimedia equipments on loan to students and teachers for learning purpose.

\section{Services}

User education/information literacy classes. Information literacy programmes are the most important tasks of the library (IFLA); librarian should be responsible for the teaching (SLA); integrate IL standards correlated to the state standards; librarian is the key person in delivery of IL skills across the curriculum (CILIP). Recommended: Satisfactory IL classes are provided regularly; Exemplary - IL classes are provided correlated to local/nation standards.

Library Orientation. Basic introduction to the library should be given to all new students (CILIP). Recommended: Satisfactory - customized orientation provided for all new students and staff; Exemplary - as above plus extension to parents and use of ICT such as virtual library tour etc.

Library classes, eg for RBL, special topics etc. Students complete all resourcebased projects required (Minnesota). Recommended: Satisfactory - classes provided for general library instruction and on-demand by teachers; Exemplary - as above plus use of pathfinders and ICT for special topics.

Reference and circulation. Loans desk should not present a barrier to effective interaction with any user (CILIP); circulation desk should not create a barrier to users (Massachusetts). Recommended: Satisfactory - low rise circulation desk; Exemplary - low rise circulation desk and self-charging system, plus distinct reference and circulation desks.

Interlibrary lending. Library staff borrow materials from other libraries (South Dakota). Recommended: Satisfactory - cooperate in local school interlibrary loan system; Exemplary - cooperate in local school interlibrary loan system and nationwide school interlibrary loan system. 
Library website. School website is a means of communicating with parents (CILIP); library media teacher should maintain a school library website (CSLA). Recommended: Satisfactory - introductory library web pages; Exemplary - up-to-date library website with breadth and depth.

Online catalogue (OPAC). Card index system for small collection, computerized system for larger collections (IBO); must provide public access catalogues (IFLA). Recommended: Satisfactory - OPAC that matches performance specifications; Exemplary as above, including remote access.

Remote access to library services (e.g. from home). 51 percent (Minnesota). Recommended: Satisfactory - students gain remote access to part of the library services; Exemplary - students have full library services through remote access.

Internet access. 92-95 percent of libraries have Internet access (Texas); sufficient for at least half a class to use at any one time (CILIP); must have computer work stations with Internet access (IFLA). Recommended: Satisfactory - Internet access; Exemplary sufficient bandwidth for a class to use at any one time.

Information policies. Transparent and up-to-date policies should be drafted jointly with teaching staff and senior managers, subject to regular review (IFLA); involve stakeholders in policy making, reviewed annually (CILIP). Recommended: Satisfactory appropriate policies in place; Exemplary - as above plus policies reviewed annually by a committee formed by stakeholders.

Opening hours. During lesson time and preferably outside these hours (IBO); school hours including break and lunch times plus before and after school hours (CILIP); 30-40 hours weekly during school hours (Minnesota). Recommended: Satisfactory - flexible access for 35 hours weekly during school hours plus one-half hour before and after school; Exemplary - flexible access over 40 hours weekly during school hours plus at least one hour before and after school.

\section{Human resources}

Teacher Librarian(s)/certified school librarian - appropriate qualifications. Ongoing in-service training, continuing professional development, conference attendance etc: 401-800 students will have 1 full time certified media specialist (Massachusetts); 300-799 students 2 FTE certified librarians (South Dakota). Recommended (1): Satisfactory - at least 1 FT teacher librarian; Exemplary - more than 2 FT teacher librarians. Degree or 
postgraduate qualification in librarianship or information management (CILIP); professional librarian has a degree in information and library science or a degree in another subject with a postgraduate diploma/certificate in librarianship (IB). Recommended (2): Satisfactory professional librarian with a degree of librarianship; Exemplary - professional librarian with a postgraduate qualification in librarianship or information management. School provides training to school librarian (CILIP). Recommended (3): Satisfactory - school provides professional development training in educational purpose and training sponsorship for school librarian; no Exemplary recommendation.

Para-professionals - appropriate qualifications. Ongoing in-service training, continuing professional development etc: Library should have 1 paraprofessional assistant to 500 students (IBO); 401-800 students will require 2 FT support staff support library media specialist (Massachusetts). Recommended (1): Satisfactory - 1 paraprofessional to support librarian; Exemplary - at least 2 FT paraprofessionals to support librarian. Library assistant requires clerical skills, technological knowledge and basic library training (IFLA); FT support staff with broad based skills (Massachusetts). Recommended (2): Satisfactory require basic library skills; Exemplary - require both library skills and technical knowledge.

Student helpers - appropriate training. Should not be considered as substitutes for trained library staff, requires supervisor and training (Nebraska). Recommended: Satisfactory - a student librarian programme is established; no Exemplary recommendation.

Volunteers - appropriate training. Work as support based in school library activities (IFLA); Library media professional responsible to train adult volunteers, systematic training for volunteers (CSLA), satisfactory provide training to volunteer; exemplary provide orientation and schedule to volunteers, volunteers assist in many ways, not solely operated in any program (Minnesota). Recommended: Satisfactory - volunteers are welcomed by library and trained appropriately; no Exemplary recommendation.

\section{Collaboration/networking: recommendations}

The following requirements would be applied to the Satisfactory level; there are no Exemplary measures.

Collaboration with teachers. Evidence of participation in curriculum development, e.g. member of the curriculum development committee (or equivalent; ongoing participation in resource based units of study; collaborative collection development.

Collaboration with other schools. Evidence of communication with other teacher librarians for joint activities, eg interlibrary lending, advocacy, reading activities (e.g. Battle 
of the Books, International School Library Day) etc.

Communities of practice: Evidence of networking with other school librarians for professional development, regular meetings, sharing of ideas etc.

Collaboration with public libraries. Exploring collaborative collection development, information skills instruction etc.

Collaboration with academic libraries. Visits by senior students to experience academic library environment, borrowing privileges for advanced students etc.

\section{Further study}

This paper represents an exploration of the potential components of an accreditation scheme. Further investigation is required to confirm that the recommendations are reasonable, i.e. they can be achieved (or surpassed) by a critical mass of IB and international schools. Ideally this would lead to a piloting of the scheme, across continents.

\section{References}

Abilock, D. (2004). Standards and guidelines for strong school libraries. Retrieved January 30, 2008, from http://www.schoolibrary.org/pub/pdf/taskforce.pdf

Australian Association of School Librarians, \& Australian Library \& Information Association. (2007). ASLA Standards for the 21st-Century Learner. Retrieved February 25, 2008, from http://www.ala.org/ala/aasl/aaslproftools/learningstandards/standards.cfm

Book Trust School Libraries Research. (2007). Booktrust School Libraries Research. Retrieved May 1, 2008, from http://worcestershire.whub.org.uk/home/wcc-lib-schoolsbooktrust_recommended_spending_figures.pdf

CILIP. (2004). The CILIP guidelines for secondary school libraries (2nd ed. ed.). London: Facet.

Committee for IB Librarians in Africa/Europe/Middle East. (1999). Guidelines for School Libraries. Retrieved February 2, 2008, from http://www.ibaccalte.schools.net.au/IBLibraries/IBguidelines2A.html

Dalrymple, P. W. (2001). Understanding accreditation: the librarian's role in educational evaluation. Libraries and the Academy, 1(1), 23-32.

Ester, G. S., \& EGS Research \& Consulting. (2001). texas school libraries: standards, resources, services, and students' performance. Retrieved May 5, 2008, from http://www.tsl.state.tx.us/ld/pubs/schlibsurvey/index.html

International Baccalaureate Organization. (2007). International Baccalaureate. Retrieved 4th December, 2007, from http://www.ibo.org/

Lance, K. C., \& Loertscher, D. V. (2002). Powering Achievement: School Library Media Programs Make a Difference: The Evidence Mounts (2nd ed.). California: Hi Willow Research \& Publishing. 
Massachusetts School Library Media Association. (1997). Standards for School Library Media Centers in the Commonwealth of Massachusetts. Retrieved April 12, 2008, from www.doe.mass.edu/mailings/1997/cm050797.pdf

Missouri Department of Elementary and Secondary Education. (2005). Standards for Missouri School Library Media Centers. Retrieved May 5, 2008, from http://dese.mo.gov/divimprove/curriculum/standards/05standards.pdf

National Library of Canada. (2001). Elementary and Secondary Schools: The Role, Challenges and Financial Conditions of School and School Library Resources in Canada. Retrieved April 22, 2008, from http://epe.lac-bac.gc.ca/100/200/301/nlc-bnc/elementary_secondary_schools-ef/9/14/index-e.html\#b4

Saetre, T. P. (2002). The IFLA/UNESCO School Library Guidelines 2002. Retrieved April 30, 2008, from http://www.ifla.org/VII/s11/pubs/school-guidelines.htm

School Library Association. (1989). School libraries : steps in the right direction : guidelines for a school library resource centre. Liden, Swindon :: the Association.

Slyfield, H. (2001). School Libraries in New Zealand. Retrieved April 18, 2008, from http://www.natlib.govt.nz/catalogues/library-documents/school-libraries-in-nz

South Dakota Library Association, \& School Library Standards Committee. (2005). South Dakota School Library Standards. Retrieved April 10, 2008, from www.sdlibraryassociation.org/pdf/schoollibrarystandards.pdf

U.S. Department of Education. (2006). Minnesota IB Program profile Retrieved February 27, 2008, from http://www.ed.gov/searchResults.jhtml

Wikepedia. (2007). IB Diploma Programme. Retrieved 4th December, 2007, from http://en.wikipedia.org/wiki/International_Baccalaureate

\section{Statement of Originality}

This statement certifies that the paper above is based upon original research undertaken by the authors and that the paper was conceived and written by the authors alone and has not been published elsewhere. All information and ideas from others are referenced. 